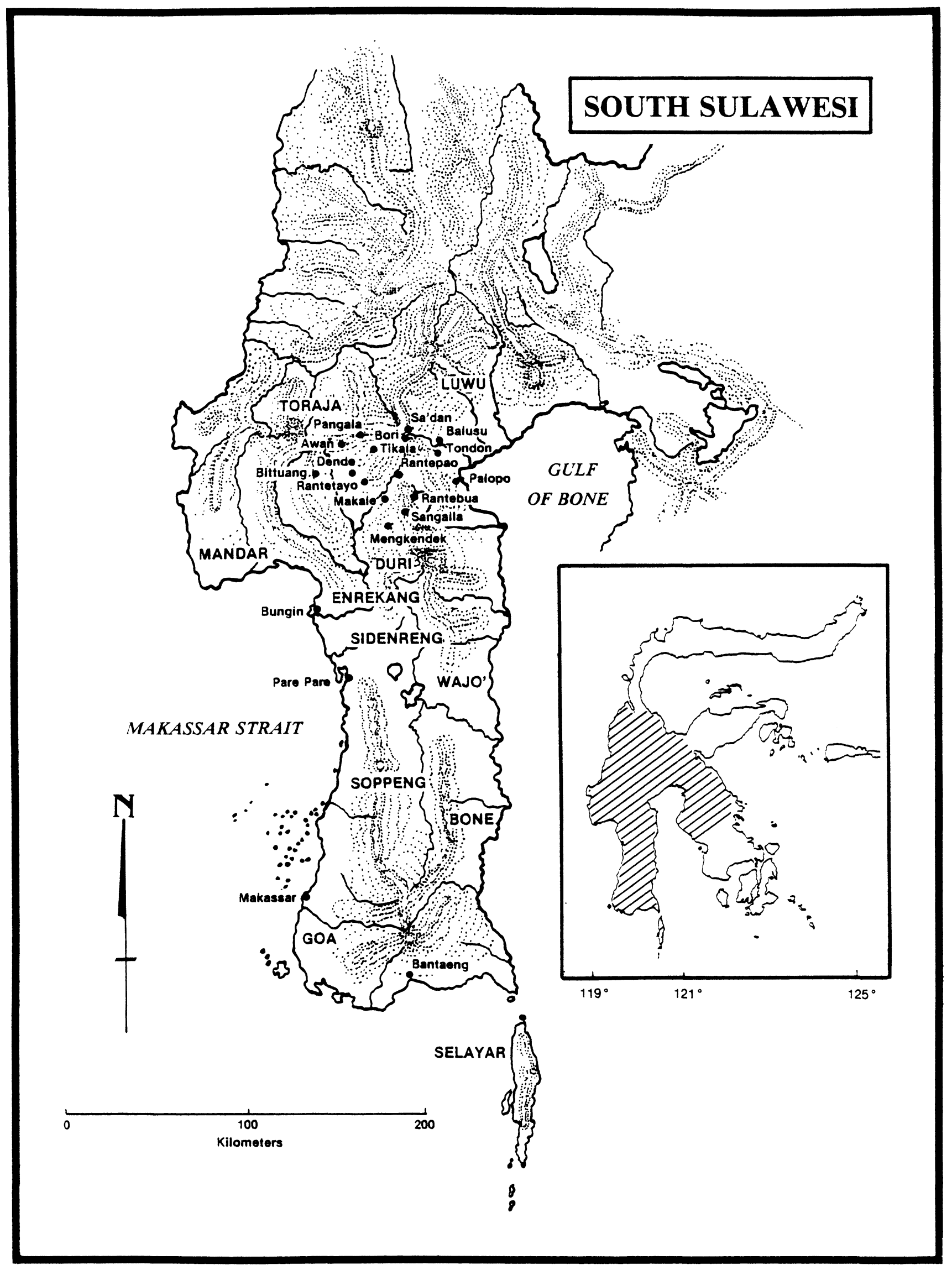




\title{
GOVERNMBNT AND MISSION IN THE TORAJAN WORLD OF MAKALE-RANTEPAO
}

\author{
Terance Bigalke
}

Religion, in highland South Sulawesi in the second decade of the twentieth century was not treated with the neutrality claimed by the Dutch for their rule in the Indies. A long and costly war had just been concluded with the Acehnese, and Islamic organizations on Java were showing signs of vitality that troubled the colonial authorities. Dutch officials throughout those islands which had substantial Muslim populations and still unconverted groups of highlanders were, then, concerned over the potential of a politically militant Islam. This caused the government to focus more attention on contiguous highland populations in provincial policy planning than their numbers warranted. So it was that the Torajan world was not left to make its slow accommodation with the Islamic lowlands of South Sulawesi.

Dutch officials operated on the assumption that the mere proximity of Bugis Muslims (who had already penetrated and converted inhabitants of the foothills of Enrekang and Duri to the south) would lead to large-scale Torajan conversion to Islam. Islam was perceived as an advancing tide that could only be stopped by building a bulwark in the highlands; isolation was the only way to preserve the heathens from Islamic conversion and to save them for later conversion to Christianity. Breedveldt Boer, assistant resident of Luwu, summed up the government position generally put forward in this period:

Greater security of persons and goods since our arrival [in 1905] had resulted in more contact--chiefly through trade--between coastal peoples and heathen ethnic groups. Thus, a fraternization is underway between the former oppressors and the oppressed, the Muslims and the heathen, a fraternization and mingling which will increase still further as the economic development of the land and people increases. Although there is much to rejoice in about development and it cannot be enough supported by the government, there lies in this fraternization the future evil that the heathen, in the first place in the vicinity of Rantepao and Makale, will more easily than previously be converted to Islam. Torajans who have temporarily moved to Palopo to seek work with traders or Europeans, do not eat pork because they feel self-conscious among Muslims; indeed, the number that undergo circumcision for this reason is also very great.

All this together means, I believe, that it is high time to begin with evangelization, not only in Rantepao and Makale such as the present plans call for, but in the whole heathen region. . . .1

1. Breedveldt Boer, "Memorie van overgave, van de aftreden Assistent-Resident van Loewoe," pp. 65-66 (Palopo, 1913, in my possession). 
Several interesting points emerge from this commentary. One is the way in which the government was so willing to dichotomize the groups involved into "coastal" and "heathen," not ordinarily considered a parallel construction. Coastal, as the Dutch so rightly understood in the Indonesian context, did indeed mean Muslim, and usually this variety of religious outlook was associated with a fairly thorough-going Islam. "Heathen," on the other hand, was correctly used as a synonym for "highlander" at this time, since these were the only pockets of population in the archipelago that remained isolated from at least a nominal conversion to Islam.

Another point is the tendency to perceive the Torajans and Bugis as enemies, as oppressed vs. oppressors. Certainly there was basis for such a generalization, but it missed the essential features of the interaction between leaders of the Torajan and Bugis communities, that in part explained the successful exploitation of Torajans by the Bugis. This undifferentiated view of both the Bugis and Torajan was a convenient one for the Dutch to hold, given their concern over the spread of Islam, and it came to assume a place in the pantheon of unexamined assumptions that dictated Dutch policy. The Bugis were continually portrayed as the strong, the Torajans as the weak. In its stripped-down version presented by a mission spokesman, the argument ran like this:

The Bugis are a mighty people. One finds among them keen seafarers and their trade activity had already stretched throughout the Indies by the time of the Company.

As a seafaring folk, they have obtained a certain worldly wisdom. Also by means of their religion they have made contact with Arabic elements, with whom many have gone to live.

The Bugis are thus more advanced than the Torajans. Where the Bugis appear, they supersede the Torajans. Where they marry Torajans, one finds little of the Toraja-type in their offspring but rather a thoroughly Bugis type. ${ }^{2}$

Extending this reasoning, the same spokesman argued that the Bugis had not wanted to convert Torajans prior to the coming of the Dutch because they were easier to exploit that way. Now however, since the Dutch provided political leadership that prevented these abuses from continuing, the Bugis were out to dominate the Torajans spiritually.

Neither government nor mission representatives gave the Torajans much credit for an autonomous response. Although there had been little actual conversion of Torajans to Islam in the highlands, the Dutch drew examples from those Torajans living in Muslim regions who had appeared willing to acquire some of the outward forms of Islam. We have seen Boer's account of this phenomenon in Palopo. Another major source of examples was the large population of former slaves returning from Bone and Sidenreng who had been released as a result of the conversion of slavery to debt bondage by Governor Kroesen. Of the estimated 12,000 Torajans who had been seized for slavery and transported to the lowlands, about one-third had gone back before the 1911 deadline by which Torajans could legally leave the Bugis lands. Some would not return because they had been well absorbed into lowland life and frequently had converted to Islam. ${ }^{3}$ Those converts to Islam who did return to the highlands became

2. A. A. van de Loosdrecht, Alle den Volcke [hereaf ter ADV], June 1915, p. 40. Alle den Volcke was a mission monthly journal appearing in the Netherlands.

3. Boer, "Memorie van overgave," p. 111. 
a sudden new focus of concern for the Dutch administration, as shown in this 1910 report:

[C]onversion (to Islam) is also promoted by the return of many former Torajan slaves, who from much time in slavery in Sidenreng and Bone embraced Islam. The disappearance of [Islamic influence from the highlands] is out of the question, as indicated by a report from the controleur of Mandar that Torajans here and there are beginning to regard pigs as unclean animals. 4

The author of this report did not carefully distinguish his cases, lumping the returning Torajan slaves together with Torajans in Mandar (the west coast of Central Sulawesi) who were beginning to observe a pork taboo. It would indeed have been fascinating to observe the Torajan slaves as they once again took up residence in the highlands if they were now regarding pigs as unclean. The pressure exerted on them to resume eating pork would have been very heavy, given the ceremonial importance of the meat. Because there is almost no further mention of this phenomenon, however, one is inclined to conclude that the returning slaves did not form a discrete community of Torajan Muslims, though as individuals they may have remained Muslim. But in Mandar Torajans inhabiting the lower hills near the shore had begun to respond to influences from the coast and convert to Islam. Where physical geography did not divide Bugis and Torajans discretely, coastal culture increasingly penetrated the highlands resulting in a religious dichotomization of people locally referred to as "Toraja Salang" (Islamic Torajans) and "Toraja Kapiri" (literally, "Kafir" or "pagan" Torajans, obviously from a Muslim perspective).s

\section{The Coming of the Mission}

Set against their concern that Islam was penetrating the highlands of South Sulawesi, Netherlands Indies authorities in Makassar sought to encourage mission societies to take an interest in the region. Provincial officials permitted Luwu's assistant resident, Breedveldt Boer, to explore possibilities with mission groups, inviting them to observe the situation in Makale-Rantepao and develop plans for its conversion. Largely for financial reasons the missions proved unable to respond to the government's invitation, though Colonel Covaars of the Salvation Army did visit the highlands in January 1912. Boer was then forced to fall back on engaging an assistant minister from the Protestant Church of the Indies (hereafter "Indies Church") to make a brief visit to Makale- Rantepao in March of that year.

The history of the Indies Church made it a seemingly unlikely candidate for an assignment whereby it would pioneer Christian proselytizing in highland South Sulawesi. An early creation of the VOC, it had maintained its identity as a colonial state church long after the official separation of church and state in the Netherlands. The nineteenth century rise of pietism and religious revivalism that created mission societies in the Netherlands left the Indies Church largely unaffected, though it was put increasingly on the defensive as these societies actively sought permission to open mission fields in the Indies. Almost solely because the state revenues it received enabled it to

4. Adatrechtbundel IX, Series P, Zuid Celebes, No. 3 (The Hague: Nijhoff, 1914), pp. 239-40.

5. Boer, "Memorie van overgave," pp. 22; 54; 66-67. 
hire an evangelist, the Indies Church now found itself expected to advance the faith aggressively into the highland regions of Sulawesi. It found itself in this position because the state perceived its own interests served by the Church's presence there. Thus while the Indies Church changed its mission to meet new circumstances in Holland and the Indies, its historical role as quiet servant of the government's interests remained constant.

Assistant minister Kelling, who made the first visit for the Indies Church to Makale-Rantepao, was subsequently placed in Makale in a position jointly financed by the Church and the Governor General, who intended to subsidize evangelistic work in Central and South Sulawesi until the private missions were financially able to take it over. ${ }^{6}$ Not cut from the aristocratic mold of the full-fledged ministers of the Indies Church, assistant minister Kelling was willing to become a circuit-evangelist based for short periods in outlying areas to supervise the building of schools and placing of teachers, all seen as preliminary steps to eventually baptizing the students and (it was hoped) their families. In contrast to the record of most missionaries of the Indies Church, the number of his conversions had been phenomenal in Luwuk (northeastern arm of Sulawesi, not to be confused with Luwu) and in the Binuang district of Mamasa, west of the Sa'dan highlands. In two short visits to the Binuang district he had baptized 5,000 persons.

In Makale-Rantepao, while using less spectacular methods of conversion than elsewhere, Kelling still minimized pre-baptismal instruction before administering the sacrament. He seems to have focused his proselytizing on the sons of chiefs who were attending the government school in Makale, a Second Class Native School popularly called the "landschap" or regional school. 7 A group of twenty students were suddenly baptized without prior permission from their parents or knowledge of the government, touching off a row that left many influential Torajans embittered toward Christianity. The controleur reported that "most of the elders resigned themselves to what had happened but declared firmly that no more of their children would be permitted to convert to Christianity." Significantly in light of later events, the controleur concluded that the incident had stemmed from the failure of coordination between the government and the missionary: "Later more cooperation developed between the government and mission, with the result that in several places private village schools were built." :

Many competing interests were brought into sharp relief between 1911 and 1913. Because of its concern that Islam was an advancing tide poised to sweep over the highlands, the provincial government wanted to induce Christian conversion there with all due speed. Meanwhile, despite the activities of assistant minister Kelling, the Indies Church was still largely at odds with the aggressive

6. This and the following paragraph are based on van de Loosdrecht, $A D V$, November 1915, pp. 86-87.

7. In principle, each onderafdeeling (subdivision) town in South Sulawesi had at least one government primary school. A five year, Malay-medium primary school was opened in both Makale and Rantepao towns in 1909. Dutch authorities sought to restrict attendance to the children of headmen, whose early suspicions of Dutch intentions led some of them secretly to substitute their clients' children.

8. E. A. J. Nobele, "Memorie van overgave betreffende de onderafdeeling Makale," Tijdschrift voor Indisch Taal-, Land- en Volkenkunde 66 (1926): 9. 
evangelical spirit emanating ever more strongly from mission societies in Holland, and it tried to slow the entry of the private Dutch mission societies into the places where it was beginning to proselytize. The Datu of Luwu, who in the eyes of evangelists and government officials represented militant Islam, was equally opposed to the missions' entry and did his best to see that no funds from the budget of Afdeeling Luwu went to subsidize any Christian proselytizing. Nonetheless, by 1913 both the Indies Church and the Datu had lost out; and it was through a resident missionary sent by the Calvinist Mission Alliance (GZB), subsidized from the Luwu budget, that the government began to lay the foundation for establishing Christianity in the highlands.

The GZB missionary A. A. van de Loosdrecht came to Makale-Rantepao by way of the Mission Institute located near Leiden. Dominated by the methods of the famed pair of Dutch missionaries, N. Adriani and A. C. Kruyt, the Institute's approach combined a wide variety of skills in ethnography, carpentry, medicine, teaching, and, of course, preaching. Teachers at the Institute contended that a good cultural understanding of the people to whom one ministered was necessary before one could hope to manipulate the religious and social system in ways that would lead to Christianization. By finding common elements, pouring new wine into old skins as it were, the religious transformation would come about more profoundly. Tinkering with symbolic systems rather than overhauling them posed less likelihood of provoking an adverse reaction and promised a more genuinely held Christianity.'

On his maiden journey inland from Palopo to Rantepao, the GZB missionary, van de Loosdrecht, spent a night at the government rest house midway to his destination. Not speaking much of the Torajan language (Tae') and still rudimentary in his Malay, he attempted to instruct one of the porters carrying his belongings to wake him in the morning by knocking on the resthouse door. The difficulties inherent in transmitting this lesson in alien forms of communication soon became all too apparent when the porter attempted to beat down the door in the manner he believed he was emulating. We are left to assume that the missionary rose on his own the following morning. 10

After experiencing in miniature, then, some of the difficulties that would confront him in the Sa'dan highlands van de Loosdrecht arrived in Rantepao. Having come to convert its people, he would first have to communicate notions foreign to the Torajan experience. To succeed in his own mission he would have to convince Torajans of the significance of the innovations he offered. And, as with the door, Torajans might receive a message very different from the one he intended to convey.

Before settling in Rantepao, van de Loosdrecht and his wife (who had hitherto remained in the Luwu capital of Palopo) spent three months in Posso with the Dutch missionary Kruyt, observing his twenty-year-old mission. a1 (Though located a considerable distance from Makale-Rantepao in Central Celebes, the Posso highlanders did have cultural traits in common with Sa'dan highlanders.)

9. A. M. Brouwer, "The Preparation of Missionaries in Holland," International Review of Missions [hereafter IRM] 1 (1912): 229-39; and G. A. Gollock, "The Present Outlook of the Preparation of Missionaries," IRM 13 (1924): 385.

10. Van de Loosdrecht, $A D V$, February 1914, p. 16.

11. Van de Loosdrecht, $A D V$, May 1914, pp. 37-39. 
Four Torajan youths--one a nephew of Pong Maramba, 12 the powerful headman of Rantepao--accompanied the van de Loosdrechts to this foreign highland society as Tae' (Sa'dan Toraja) language tutors to prepare them for their return to Rantepao. During this time the Tae' language appears to have come easily to the determined missionary and his wife, as did impressions about the power a missionary had to transform East Indies societies. Kruyt had in many ways combined the functions of government and mission in the ten years prior to the Dutch expansion of their authority to the region in 1905. With such a foothold, the mission tended to mold the character of the later arriving Dutch administration. Without having to identify with the secular state, Kruyt's mission had received ample cooperation from it. As Ida van de Loosdrecht later wrote to Mrs. Kruyt, "We of ten say to one another, 'how wonderful for Posso that the mission preceded the Government.'"13

Back in Rantepao the ambitious missionary set out to recreate the city on a hill that he had witnessed in Posso under the seasoned master. With a sense of urgency, he visited the major districts of Rantepao, met their headmen, and, in a meeting also attended by the controleur, encouraged them to build schools in their kampung. 14 "Of all the means that a mission has at its disposal to gain entry to the people," he wrote soon afterwards, "the school is surely one of the most prominent." And while his approach was aimed at the future adults of the society, he did not concede those already grown up: "The way to the heart of a father and mother in mission work goes through the child. Children attach themselves quickly to their teachers, who have a knack of getting on with them even more than their parents do." 1 s

By pushing education, the mission hoped it had found a means by which to enter traditional societies without creating the type of resistance that would be engendered by a direct attack on traditional religious values. The problem remained to convince district headmen and their village clients that they themselves would derive some benefit from the schools. Van de Loosdrecht found the traditional elite initially cautious but generally willing to consider allowing schools to enter their tondok (district).16 In retrospect, it appears that they were probably less enthusiastic than the missionary reported to his home board.17 The headmen were still in the process of evaluating the behavior of the "Kompania," the name they still applied to the Dutch government over a century after the demise of the Dutch East Indies Company. It appeared to them that the school was one of the forms of tribute demanded by the new patron state. For some years many continued to believe that it was a disguised means of drafting their sons into the colonial army and taking them away from

12. Sampe Pandin, interview, January 22, 1978, Ujung Pandang.

13. Letter from Ida van de Loosdrecht to Mevrouw Kruyt, May 25, 1914, Rantepao. (Archive, Hervormde Kerk, Oegstgeest; hereaf ter AHK.)

14. Van de Loosdrecht, $A D V$, March 1914, p. 23.

15. Van de Loosdrecht, $A D V$, October 1914, pp. 85-86.

16. Van de Loosdrecht, $A D V$, March 1914, p. 23.

17. D. Crommelin, "Rapport over het bezoek aan het zendingsterrein van den Gereformeerden Zendingsbond in Rantepao en Makale, Juni 1918," pp. 2-3 (AHK); E. A. J. Nobele (untitled secret government report on the death of A. A. van de Loosdrecht, by Assistant Resident of Luwu), Palopo, August 20, 1917 (AHK). 
the highlands. Thus while on the surface they acquiesced to this peculiar new form of tribute, they also tried to circumvent it in various ways.

Van de Loosdrecht's first year in Rantepao can be seen as a cautious effort to undo what Kelling of the Indies Church had done during his short tenure in the Sa'dan highlands, as well as to counterbalance the "bad examples" set by both the Dutch and Malay-speaking Christians stationed in Makale-Rantepao with the NEI administration. 1: Pragmatically he accepted the hasty baptismal techniques of evangelist Kelling for their value in slowing the advance of Islam, while he maintained that their use had produced a Christianity that was superficial at best. He ridiculed the cautious forays made to the town of Makale by the elitist minister of the Indies Church stationed in Makassar, Kyf tenbelt. Kyftenbelt preferred to spend an hour a week with the five Christians in Makale town and the rest of the week recovering, van de Loosdrecht complained; never would he dream of setting foot in the villages. What was worse, Kyf tenbelt's wife insisted on parading about under a white umbrella like some royal personage, followed by an entourage of servants bearing her daily necessities. 19

Van de Loosdrecht himself retained many of the stereotypes of "the native" common to the Dutch colonials of his time and tended to patronize Torajans as children who needed tutoring. Yet he understood the inherent limitations of the elitism of Kyftenbelt and others like him in the Netherlands Indies Church who were content to wait for potential converts--shorn of their traditional explanatory systems through education, employment, or migration--to surface in urban centers. By contrast, the strategy of the hill country evangelist of the twentieth century was to bring about that transformation in place.

Convinced of the importance of the elite to any successful mission venture in Makale-Rantepao, van de Loosdrecht sought to develop personal relationships with key district and village headmen. Within a short time he identified Pong Maramba of Rantepao, $\mathrm{Ne}^{\prime}$ Mattandung of Balusu, and Tandibua of Pangala as central figures among the onderafdeeling (subdivision) Rantepao elite. Frequently he visited their kampung, especially those of Maramba and Mattandung whose houses were not far away from his own. Maramba did not go out of his way to reciprocate the missionary's interest in him, but, after a few fruitless attempts, van de Loosdrecht finally managed to find the headman at home, having just returned from a death feast. Their exchange that evening was, by the missionary's account, a warm one in which he avoided outright proselytizing. The women in Pong Maramba's household paid a return visit to Mrs. van de Loosdrecht some days later, displaying great curiosity over the bed, sewing machine, and church organ as they led the somewhat astonished woman about her own house. 20 An amiable enough relationship had begun to develop, it would seem.

With $\mathrm{Ne}^{\prime}$ Mattandung of Balusu, relations were similarly cordial at first. Van de Loosdrecht was sensitive to the fact that Balusu district was located on the western border of Luwu and he was alert to possible signs of Islamization

18. "Yes, the Christians here in general provide a poor example. They look upon the Torajans as lowly but not too low to enter into the most intimate of relationships with them." Van de Loosdrecht's letter to Kruyt, December 30, 1914, Rantepao (AHK).

19. Ibid.

20. Ida van de Loosdrecht, $A D V$, November 1914, pp. 95-96. "If Pong Maramba were to become Christian, the strength of heathendom would be forever broken," wrote the missionary's wife. 
emanating from this old Islamic kingdom. 21 Historically the Balusu "Puang" 22 had married into the Luwu court families, quite like their Islamicized neighbors in the adjacent Luwu Highlands; $\mathrm{Ne}^{\prime}$ Mattandung's daughter herself was married to a close relative of the Datu. Perhaps attuned to the missionary's fear that this pattern of intermarriage signalled the beginning of the Islamization of Balusu, $\mathrm{Ne}^{\prime}$ Mattandung apparently assured him that, despite the birth of a child, the father's two-year absence meant that the marriage was as good as dissolved. The missionary counted on Mattandung to provide a prime point of contact with Torajan society, just as invading Dutch troops had relied on him eight years before, when they extended their administrative control into the highlands. Nonetheless van de Loosdrecht harbored the suspicion that Mattandung retained an "inclination toward Islam." 23

While attempting to build cultural bridges directly to the headmen, the van de Loosdrechts sought allies in their children as well. ${ }^{24}$ They invited several youths from influential families to board with them, providing Biblical instruction and a Dutch Calvinist moral framework. Van de Loosdrecht depended on his boys to teach him the language and, more importantly, to form the core of the first indigenous group of guru (teachers), and guru injil (evangelists). Their high social status insured that these pioneer figures would draw attention.

Girls were trained as prospective wives for the Malay-speaking and Torajan guru. 25 Ida van de Loosdrecht taught them a Victorian morality quite alien to Torajan custom, schooled them in the basics of nutrition, hygiene, and housekeeping, and instructed them on how to use the sewing machine. These women would provide the moral and spiritual fiber for the children at home that would set the Christian household apart from the heathen. Without a pool of suitable marriage partners from which to draw, the teachers would be more likely to become embroiled in scandal with village women, and decrease the effectiveness of their religious message in a society where "[t]he children understand the whole village chronicle, know who has a quarrel with whom, who speaks scandalously of others and who has deceived another, who is esteemed and who is disdained." 26

Initially the missionary adopted a conciliatory approach toward the indigenous religion and ritual that underpinned the elite with whom he was so concerned. He took the high road of emphasizing schooling while avoiding talk about religion in his initial meetings with people. "As soon as they hear that the morals and customs of their ancestors must be changed, their favorable disposition immediately disappears and they refuse to do anything, "he wrote. 27 If he took the back door and stimulated widespread acceptance of schools, religious

21. Van de Loosdrecht, $A D V$, October 1914, pp. 88-89.

22. "Puang" was the highest term of nobility in the southern portion of the Sa'dan highlands (Makale, Mengkendek, Sangalla) as well as the eastern tondok of Sa'dan and Balusu.

23. Van de Loosdrecht, $A D V$, July 1915, p. 44.

24. Van de Loosdrecht, ADV, March 1914, pp. 23-24; van de Loosdrecht, letter to Kruyt, February 22, 1916, Rantepao (AHK).

25. Van de Loosdrecht, $A D V$, May 1916, p. 40.

26. J. Belksma, $A D V$, June 1918, p. 42.

27. Van de Loosdrecht, $A D V$, September 1914, p. 84. 
education would naturally follow. This, he assured any skeptics in the home church in Holland, was because the heathen mind did not easily distinguish between the sacred and the profane; in due course it would seem natural that religion was being taught in school. ${ }^{28}$ Surprisingly, he did not anticipate that Torajan opposition to the schools might arise out of that same unitary world view.

Van de Loosdrecht's directness and the nagging image he retained of the flourishing mission in Posso prevented him from circumventing religious issues for long, though he initially chose his themes with discretion. He told the creation story frequently and selected Abraham, Noah, and other Old Testament patriarchs to appeal to the Torajan ancestral reverence. ${ }^{29}$ The Biblical myth of the flood, which he found to be very popular, strongly resembled a Torajan myth. His use of the Prodigal Son parable further exemplified his early efforts at finding commonalities between Torajan religion and Christianity. 30 Van de Loosdrecht held a view of primitive religions having declined from an earlier purity to a corrupted state. This view implied that Torajans had originally believed in the same high god as the God of the Christians, but that through the centuries the belief had become corrupted by spirit worship. Therefore Torajans need only strip away these corruptions to reveal the high god; they need only return to belief in "Puang Matoa." The use of the indigenous name of a prominent Torajan deity for the Christian "God" as much as the missionary's emphasis on a "return"--i.e., the Prodigal Son-set a context for religious discussion that accepted much that was authentically Torajan. This fitted nicely with a strategy of conversion focused on attracting the elite.

If working through the traditional elite composed one leg of the initial mission strategy, cooperation with the Dutch administration constituted the other. Van de Loosdrecht was an acutely political man, who knew the meaning of lobbying for his causes and appeared able to locate the points in the various tiers of the East Indies administrative hierarchy where he could exert pressure. His interest in gaining active support from the government stemmed from the view he took of religious, or more broadly, cultural change: that the efforts by the mission to loosen Torajans from their cultural moorings had scant impact compared to changes induced by the East Indies administration, ${ }^{31}$ The outlawing of headhunting and trial by ordeal, abolition of the slave trade, and forced resettlement ("kampung-forming"), to take several examples, had given the traditional order a shock from which it would never recover. In providing a buffer between Torajans and their "former oppressors" the Bugis, the Dutch administration had given the formation of Torajan ethnic consciousness a "great shove." 32 But through its various modifications of tradition (in the name of preserving tradition), the government had succeeded in loosening people from their animism while providing them nothing directly to replace it. In this anomic state, "[the Torajan] himself waits for something to replace" his earlier beliefs, the missionary anticipated. ${ }^{33}$ The mission would provide that something in the wake of government-induced social change.

28. Ibid., p. 86.

29. Van de Loosdrecht, $A D V$, April 1915, p. 21.

30. Letter from van de Loosdrecht, February 22, 1916, Rantepao (AHK).

31. Van de Loosdrecht, $A D V$, August 1915, p. 60.

32. Van de Loosdrecht, $A D V$, October 1914, p. 86.

33. Van de Loosdrecht, $A D V$, June 1915 , p. 41. 
During the first year of GZB activity in Makale-Rantepao, relations with the East Indies government of ficials were not notably cordial. The government's deep anxiety that Islamic adherents would penetrate the highlands and convert the hill peoples was counterbalanced for a time by their misgivings about the blunders committed by the overly eager evangelist Kelling. His mass baptism of school-aged children without regard to the wishes of their parents raised concerns that perhaps one potential threat to "peace and security" would be replaced by another. The quality of the teaching personnel loosed upon the highlands was brought into question by the dismissal of a teacher for his swindling activities in the Makale village to which he had been assigned. Though the Indies Church mission was soon displaced from Makale-Rantepao by the arrival of van de Loosdrecht in 1913, a cloud of zealotry still hung over the highlands.

It is most ironic that zealotry should ever have been associated with the Indies Church, given its tepid record of proselytizing in other parts of the Netherlands East Indies. It was a zeal, in the Sa'dan highlands, born of the hasty efforts of the provincial government to use whatever Protestant vehicle was at hand to begin erecting a Christian buffer in South Sulawesi.

During the six years following the introduction of government schools in 1908, the authorities had regularly resorted to using troops to round up truant children of the elite and bring them to school in the towns. Van de Loosdrecht believed that such an approach could be an effective lever to help him build attendance at his village schools. He pressed for permission for elite children attending the government school to be given the option of attending the mission village schools. The controleur of Rantepao finally conceded this point, and, with that, van de Loosdrecht was able to employ the implied force of military truant officers to the mission's advantage. He reported absentees to the controleur, who had the parents of truant children arrested in their villages and taken to the Rantepao jail. ${ }^{34}$ With such heavy-handed practices, an absentee rate of 5 to 10 percent was considered high.

While attempting to maximize both direct and indirect benefits of government policy in Rantepao and Makale, the missionary and his supporters sought to have officers more sympathetic to the mission installed in the highlands. Lobbying the bureaucracy appears to have paid off by the end of 1915, just over a year after the missionary had arrived. The newly appointed controleur of Rantepao, M. R. Brouwer, was a man who shared the religious outlook of the GZB mission and who, van de Loosdrecht predicted, "will not withhold his unqualified support from us." 3 s At about the same time, Breedveldt Boer was replaced as assistant resident of Luwu by E. A. J. Nobele, whose sympathy for the mission and concern for rust en orde had grown with the incidence in uprisings that had begun to characterize South Sulawesi after 1914, some of them inspired by Islamic religious leadership. The assistant resident began to push for the GZB to extend its mission activities into the highlands of the onderafdeeling of Palopo which was the Islamic stronghold in Luwu. By late 1915 any reluctance within the Dutch administration to cooperate with the mission in afdeeling Luwu had been removed: "it is wonderful that Assistant

34. Letter from A. A. van de Loosdrecht to A. C. Kruyt, June 8, 1914, Rantepao (AHK).

35. Letter from A. A. van de Loosdrecht to A. C. Kruyt, December 30, 1914, Rantepao (AHK). 
Resident Nobele so strongly cooperates," wrote Kruyt in reply to a letter from van de Loosdrecht. 36

Torajan headmen had gone through nearly a decade of readjustment since the coming of the Dutch administration. New rules of competition had been thrust upon them, with the Pax Neerlandica imposed upon highlands that had seen so much fighting during the Bugis struggle from 1870 to 1905 , in shif ting alliances with Torajan headmen, to control the coffee and slave trade from the highlands. ${ }^{37}$ Firearms, once so prevalent in the hands of the powerful chiefs, had been turned in to the Dutch or lay rusting in the limestone caves that concealed them. The traditional system of $R a^{\prime}$, the ultimate determination of an argument by ritualized battle, had been replaced by a government court to handle those quarrels that could not be peacefully resolved by village or district heads. Duplicating the feats of great headmen such as Pong Tiku, Pong Maramba, or Andi Lolo, who forcefully expanded their land holdings just prior to the Dutch arrival, was out of the question with the regularized order that the Dutch had imposed on the Sa'dan highlands. Control of retainers had passed from such leaders' hands, except for the days of service specifically granted them as compensation for their chiefly duties, and whatever extra-legal claims they could get away with. The benefits of the coffee trade had become somewhat questionable now that the controleur of Makale-Rantepao prevented Bugis trading agents from bargaining directly with the chiefs for access to their coffee; once coffee collection was organized for government taxation in Makale and Rantepao towns after 1910, a sizeable source of chiefly wealth and power slipped from the hands of the headmen.

Although many of the traditional forms of competition for power had been diverted into more routinized channels, the elite still did retain perhaps the primary means of attracting clients, the distribution of meat. Through the ceremonial system, the patron-client relationship that for much of the year might be difficult to distinguish came clearly into view. Patrons at the death feast, for example, distributed portions of meat that "repaid" the labor clients had provided during the year. Now, without the overtly coercive mechanisms that had been available before the Dutch administration (the most direct being outright attack and seizure of individuals or an entire kampung for slavery), the sacrificial system assumed even greater importance as a vehicle of cementing patron-client relationships.

The new administration and the coming of the mission brought about opportunities as well as challenges. New symbols of power were introduced: the Dutch awarded medals of service to chiefs who had helped to put down Torajan resistance; officers' dress jackets replaced the chief's traditional clothing; and the office of pangarak (caller) was created to place some distance between the chief and those he might wish to summon. " Through the missionary came another

36. Letter from A. C. Kruyt to A. A. van de Loosdrecht, April 4, 1916, Pendolo (AHK).

37. For details on the slave trade, see Terance Bigalke, "Dynamics of the Torajan Slave Trade in South Sulawesi," in Slavery, Bondage and Dependency in Southeast Asia, ed. Anthony Reid (New York: St. Martins Press, 1983), pp. 341-63.

38. L. Weber, Verbaal 12-8-1914-76, mailrapport 1817/13 (Colonial Archive, The Hague), pp. 75-76. Laso' Sombolinggi, interview, March 2, 1978, Rantepao. G. R. Seinstra mentions pangarak along with patikin ("sword bearers," a kind of village police) and mandoro kampung (assistant village head) as officials 
potential symbol of influence, the village school. While the chiefs did not clearly understand the reason for building schools and harbored some suspicion of them, it was widely known that the government supported their construction. By building a school a chief looking for increased influence put himself closer to the light of government patronage.

Most Torajans who knew van de Loosdrecht seem to have viewed him as an extension of the Dutch administration. ${ }^{39}$ The short period during which he avoided attacking Torajan religious beliefs was generally cordial, however. Chiefs enjoyed receiving a visitor, exchanging stories with him, inquiring about his tondok, and making observations about the unusual aspects of To Belanda that they had observed. One remarked that Dutch mothers must be lax in teaching their children language, since the Dutch always went around asking Torajans what the words were for various things they saw. Another noted that he had never seen a mug like the one the missionary's wife had used to serve him coffee, and according to custom asked to take it home with him.

As Torajan chiefs began to hear messages that contradicted their system of beliefs, they responded variously. Some, such as Tandiseru, a kampung head from Tikala, announced that he would "rather be exiled than believe in Christianity"; another felt it was "preferable to die than to leave the religion of the forefathers." 40 Others sought comments on the missionary's stories from Islamic teachers they knew in the towns of Makale or Rantepao or in Luwu. They were, like $\mathrm{Ne}^{\prime}$ Mattandung of Balusu, seriously considering conversion to Islam after years of contact with Islamic elites; or they were, like Pong Maramba, continually seeking alliances that would provide the most room for maneuver: Christian when Islam pressed, Muslim when Christianity threatened. There were chiefs who saw an unabashed syncretism as the way to deal with the god of the Kompania, finding "a place for Pong Isa" (Jesus) among the deata, the host of spirits complementing Torajan deities. ${ }^{41}$ During the missionary's first year this suggestion to incorporate a new element into their beliefs was the warmest response that he received.

Much in the early teachings of the missionary sounded quite funny to Torajans but some of the stories contained similarities with those they had heard from their Muslim neighbors. The story of the crucifixion was not impressive, given their belief in the efficacy of trial by ordeal. In their view, if this god was powerful he would never have died that way. ${ }^{\star 2}$ Even more difficult to accept was the belief that each man was a sinner. The Torajan view of religious responsibility corresponded more to a system of rituals and duties that were carried out at the proper time and for the proper persons or deities. Thus a typical Torajan response to hearing that he was a sinner was that his heart was good; how could he be a sinner? The full flavor of this attitude was carried in a quotation that comes a year later than the period under review but aptly emphasizes the point: "Oh Tuan, my heart is right; I am a friend

assisting the kampung headman. All were initiated under the Dutch administration. G. R. Seinstra, "Memorie van overgave, betreffende de onderafdeelingen Makale en Rantepao" (Rantepao, 1940, in my possession), pp. 133-34.

39. Van de Loosdrecht, ADV, August 1917, p. 69.

40. Van de Loosdrecht, ADV, October 1916, p. 97; August 1915, p. 60.

41. Van de Loosdrecht, $A D V$, May 1915, p. 31; July 1915, p. 44.

42. Van de Loosdrecht, $A D V$, April 1915, p. 21. 
of the Kompania ... and my heart is right toward you, as well as toward Puang Tarongkon [the Puang of Makale] and is right toward the deatas to whom I never forget to provide offerings." 43

The Torajan fascination with death and the afterlife did, however, provide some common ground for discussion. Their most appreciative responses to the missionary came when he described the Christian vision of the hereafter. Pong Maramba, at a time when he was encouraging visits from both Islamic teachers and the missionary, once told the latter that it was as if his stories made the heavens open up for him, Maramba, to catch a glimpse. ${ }^{4}$ This sort of reinforcement naturally skewed the content of early Christian proselytizing among the Torajans, at least insofar as the missionary could still see some promise in the elite. But there were seeds of conflict in an approach that down-played the message of love and the sacrificial lamb while emphasizing the afterlife. Taking that as a point of departure, it was hard to avoid a basic commentary on Torajan funeral practice and conceptions of the hereaf ter. This opened the way to fundamental differences between the Christian conception of heaven and the Torajan conception of Puya, where the social hierarchy was believed to continue much as it had on earth. Once the more egalitarian aspect of Christianity was exposed, the fascination with "making the heavens open up" was replaced by a concern that the existing social order not be turned upside down.

While proselytizing did not force an immediate response from the headmen because there was little danger of anyone converting, the building of schools did. Generally schools received an ambivalent response from the powerful chiefs, with somewhat more enthusiasm coming from the less powerful in small districts. The school could be interpreted as another symbol of the chief's power, located as it was near his house in most villages that had a school. It could also be seen as a threat to his control of the village, since it introduced through the guru, usually a non-Torajan, a foreign element beholden to the missionary.

In principle, most of the major tondok that were pressed to build schools acquiesced, with their chiefs providing manpower and access to the materials needed for construction. Since the chiefs' retainers were doing the building, it was customary for them to be provided with meals in return for their labor. Only in Tondon did the headman refuse outright to allow a school to be built. This refusal stemmed from a dispute between the guru in the Rantepao government school and the ruling headman of Tondon over the treatment of the latter's child. After the guru was relieved of his position the resistance declined, and a new school was built in Tondon in 1916.45

The posture of the chiefs was critical in the initial years of a school's existence. Children needed a great deal of coaxing to go to school; indeed, the first few times they saw the missionary approaching for school inspection they ran from sight, crying out the characteristic whoop formerly associated with warfare."6 The sight of a "belanda" was still rare enough to inspire tremendous apprehension; eventually van de Loosdrecht sent his teachers out

43. D. C. Prins, ADV, April 1918, p. 27.

44. Van de Loosdrecht, $A D V$, December 1914, p. 102.

45. Van de Loosdrecht, $A D V$, August 1917, p. 70.

46. Van de Loosdrecht, $A D V$, October 1914, p. 87. 
alone to get the schools functioning and came himself only for their official dedication.

Once the children had been initiated into the school system, other problems arose to cause the chiefs concern. The guru regularly administered corporal punishment, disturbing not only the victims of the poundings but their parents as well. 47 This was not merely a dispute over the proper locus of corporal discipline, the home or school. Rather, it cut deeply against the Torajan ethic of how children should be raised. They believed that, if a young child were hit, his spirit could desert him, and the child would become seriously ill. Toby Volkman reports that only after a child has suffered from smallpox, the most feared disease, is it considered proper to administer a physical blow. 4

Another cause for concern stemmed from the students reactions to life in the village once they had attended school in the town. Some refused to return home to live an agricultural life, or to engage in manual labor of any sort. In Buntao, children refused to work in the fields after schooling, leading van de Loosdrecht to note with some alarm that an "educated proletariat" was in the making. While this may have been the result of life in the town as much as of the education received there, the chiefs associated the tears in the social fabric of the village with their children's going away to school. The missionary's reassurances that this was not the intended response from the children and his encouragement of education in the villages quieted some but not all their fears. 4 "

A good indication of the depth of the mistrust among the elite was the nearly universal practice of substituting their retainers' children for their own in the schools. This, naturally, made the children's resistance to manual labor all the more chilling, for it promised an unmanageable clientele in the future. The elite was afraid from the outset that the government's motive in recruiting their children was to send them to the military and take them away from the highlands. 30

Another measure of mistrust was the small number of girls sent to the schools despite constant reminders from the authorities that schools were intended for both sexes. This restraint was most notable in the large, powerful tondok, such as Rantepao, Pangala, and Makale.

We can summarize the initial period of interaction between the missionary and the elite as one of caution on both sides. The missionary exercised restraint in his choice of religious themes, his pressing for schools, and his response to the ritual systems of the Torajan. The elites listened with curiosity and a tolerance based on their awareness that local Dutch authority solidly supported the mission.

\section{Resolution: The Dutch}

When van de Loosdrecht first arrived in Rantepao he had the keen eye of a traveler who has not yet become numbed to the new things he sees around

47. Van de Loosdrecht, ADV, August 1917, pp. 69-70; April 1918, p. 27.

48. Toby Volkman, personal communication.

49. Van de Loosdrecht, $A D V$, August 1915, p. 60.

50. J. Belksma, $A D V$, June 1918, p. 43. 
him. He was immediately drawn to observing the social hierarchy around him, and apparently felt it necessary to justify the existence of the large number of "slaves" (kaunan) in the Torajan social structure. It was somewhat difficult for him to do so because of the narrow ascriptive way he defined the kaunan as "slaves," or "former slaves" rather than seeing them functionally as clients. 31 Even so he found it possible to rationalize their condition in Biblical terms, resorting to the Pauline exhortation that masters and slaves must each know their own roles. 32 Indeed, his motivation was not unlike Paul's, in that van de Loosdrecht had gone to Rantepao with the desire to appeal to the elite with his religious message, not to turn the society upside down.

In comparison with his later position, his early observations appear remarkably dispassionate and tolerant of indigenous social behaviors and structures. He attempted to sketch the social "status groups" (standen) in terms of the rulers and the ruled (the former being the puang and tomakaka classes, the latter being the "slaves" [kaunan] and debt slaves [to sandang]), limiting his remarks merely to the contention that most to sandang fell into servitude through gambling, which continued clandestinely despite strong government prohibitions. ${ }^{3} 3$ With regard to the position of women, he simply noted that they appeared to be socially more equal to $m$ en in the Rongkong hill country (northern Luwu) than they did among the Sa'dan highlanders of Rantepao. s4

Within a few months, however, after the missionary had begun to encounter some resistance from the elite whose position he had initially sought to rationalize, he took a much more critical view. He began sending home to mission headquarters unflattering information on the Torajans, information he had undoubtedly noted previously: "human heads adorn the facades of houses in Bori" and the inhabitants there used to practice cannibalism, according to an old Tominaa.ss In July 1915 having come up square against the powerful headman of Rantepao he pessimistically assessed the chances of conversion: "Pong Maramba is not for it, though the missionary is on a good footing with him. Brother van de Loosdrecht expects a violent struggle in Rantepao." s6 Indicating that he had moved on from his view of the Torajan as "child-like" in many ways, he now concluded that " $(t)$ he worldly wisdom is much greater than one thinks and the sins are more awesome." As van de Loosdrecht came to view the elite less as naive wards than as shrewd adversaries, his approach to evangelizing became more bold. It was as though he had decided to reject the recalcitrant old notables and to begin making an appeal to the lower orders of Torajan society.

Our first clear indication of this comes in the western tondok of Rano. It was from this outlying district and from simbuang further west that the missionary had received his first rural expressions of interest in conversion, which prompted him to declare that "the signs are such that Makale may be

51. For a discussion of this terminology, see Bigalke, "Dynamics of the Torajan Slave Trade," pp. 357-60.

52. Van de Loosdrecht, $A D V$, December 1914, p. 102.

53. Van de Loosdrecht, ADV, March 1915, p. 11.

54. Van de Loosdrecht, ADV, April 1915, p. 21.

55. Van de Loosdrecht, ADV, August 1915, pp. 62-63.

56. Summarized from letter written July 22, 1915, reported in ADV, May 1916, p. 40 . 
won over to Christianity before Rantepao." s? It is unclear just why he should have chosen to open his offensive against the elite in a place where the elite itself was most interested in converting; it may have been a strategic blunder. But open it he did, with a Torajan-tailored version of the "rich fool" parable, told in terms of rice barns, water buffalo, and fat pigs owned in profusion by a rich man named Pare La'bi ("Excessive Rice"). The crowd that gathered to hear this parable expressed great sympathy and affection for the wealthy Pare La'bi whom van de Loosdrecht painted as a gross materialist. He labeled this rich man a fool because his wealth had prevented him from attending to what really mattered, the spiritual dimension of his life. Van de Loosdrecht records that the inhabitants of Rano responded with shock to the contention that Pare La'bi could be out of favor with any deity, given the man's great wealth: "My application fell like a thunderbolt on the many gathered. Such a message was wholly new to them: a 'rich' man called a 'fool' by God. People sat dismayed; with open mouths they listened further to my explanation and the reasons that it was foolishness in God's eye. That God loves the poor as well as the rich was not something that came to the Torajan mind." sa More significant than the message that a rich man could be a spiritual fool was the correlation that the missionary began to draw between the wealth of some and the oppression of others: "A rich man is held in a kind of holy fear by the Torajan. People put him on a pedestal. Let him extort villagers, swindle, in a word be heartless, but he remains in their eyes great and men call him 'good' because the blessing of the gods is upon him." Over the next eighteen months his class critique sharpened. He began openly to censure the basic inequalities in Torajan socioeconomic relationships, portraying them as having been exacerbated by the complicity between the Bugis and Torajan elites during the days of the slave trade. "The rich are loveless and hard toward the poor," he lamented. "Adat and people's rights have suffered a great deal ... under this unchaining of passions. Some families have especially known how to profit from this situation and how to gain access to excessively large landholdings. $s 9$ The result of this greed for rice land, he said, had been to reduce most Torajans to tenants or laborers without control of even a small piece of wet-rice field. "For the greatest part of the year they possess no rice and feed themselves on greens that their wives collect in rice fields."

The plight of those labeled "the dispossessed" became his major focus, replacing his initial focus on the old guard, whom he now defined as oppressors. And he broadened the application of "the dispossessed" to include the impoverished tomakaka as well as kaunan, attributing the plight of the former not to land seizures but to the Torajan death cult. He correctly assessed that a landholder would, under economic duress, pawn his rice fields to get buffalo to meet his sacrificial obligations at a death feast. Often, this land would pass permanently from its owner's control to that of the pawnholder, who gained ultimate right of disposal. He argued that to halt the trend toward landlessness, the extent of sacrificial cutting had to be restricted: "So long as the death feasts are not limited, this process will continue and the gap between deep poverty and great riches will assume still graver forms." 60

57. Ibid., p. 40.

58. Van de Loosdrecht, $A D V$, February 1916, p. 15.

59. Van de Loosdrecht, $A D V$, January 1918, p. 6.

60. Van de Loosdrecht, $A D V$, February 1918, p. 9. 
While one might applaud the social conscience that stirred the missionary's soul, and acknowledge the genuine sense of revelation that came through his inquiries into Torajan history and social structure, one must remain aware that the motivations driving his inquiry did not exclude self-interest. Behind his revelation lay the gradually awakening realization that the ritual order and the socioeconomic order upheld one another: "No wonder most chiefs are against Christianity," he mused, stripped of his own naivete. 1 During the time he had conceived of his task as converting the whole of Torajan society through converting the elite, he had taken a Pauline view of the relationship of ruler to ruled, each with his duty to obey. Once he saw the inefficacy of this strategy for purposes of conversion, he allowed himself to entertain the possibility of social engineering-for which he so admired the power of the government--as a substitute.

Radical as was his attack on the death feast, it assumed even greater gravity as it came in the wake of a determined attack on gambling and cockfighting. Little had been done effectively to prohibit gambling in its various Torajan forms (including some imported by the Bugis) until the mission arrived in Makale-Rantepao. The government had gradually reduced the number of days permitted for cockfighting, which took place in the period between the death feast and burial, and was associated with religious conceptions of conveying the sumanga (life-force) of the deceased to the afterlife. Van de Loosdrecht sought further to reduce the number of days permitted, and restrict the practice solely to the elite.62 His active opposition to cockfighting became so well known that headmen of ten teased him about it. One man assured the missionary with a straight face that he would happily turn Christian if the government would first permit him one uninterrupted year of cockfighting; on another occasion, when the missionary approached him at a village gathering on Sunday, the headman prodded: "Why not allow us to fight cock at this service?" ${ }^{3}$ The humor, how ever, barely concealed the growing tension between van de Loosdrecht and the elite, who feared a total ban on the sporting ritual.

The GZB mission became politically very secure after the appointment of Brouwer as Rantepao controleur and the promotion of Controleur Nobele from Makale to the assistant resident position in Palopo. The new Makale controleur was less openly sympathetic to the GZB and to Prins, its neophyte missionary in Makale, but he did not pose an obstacle to the spirit of mission-government cooperation that had emerged with the blessing of the new assistant resident. Both Brouwer and Nobele were sensitive to the deterioration over the course of 1915 of what van de Loosdrecht had termed "the more gratifying spirit that had prevailed in Toraja initially...."64 They saw this more surly spirit as a spillover from the series of local rebellions that had broken out in Luwu that year, and resolved to use a show of force to prevent any further spread of dissension to Makale-Rantepao. Thus when van de Loosdrecht's probings into village life brought to light some of the unsavory but conventional activities of headmen in preserving or expanding their wealth and influence, the Rantepao controleur, backed by the assistant resident, elected to open official investigations.

61. Ibid.

62. E. A. J. Nobele, untitled secret report over the death of A. A. van de Loosdrecht (AHK).

63. Van de Loosdrecht, $A D V$, January 1918, p. 4.

64. Van de Loosdrecht, ADV, August 1917, pp. 68-69. 
This was a reversal of the government's earlier decision, arrived at after some initial hesitation, that the activities of the elite prior to Dutch arrival were not subject to official prosecution; the ongoing implication for the elite had been that, within certain limits, things would go on as usual at the village level. By December 1915 the government was beginning to show its new policy in dealing with headmen's affairs.

In light of the official support van de Loosdrecht had begun to receive, he planned a show of strength by holding a Christmas feast in Rantepao which he hoped would be attended by the influential headmen of the district. The feast would blend the Torajan custom of slaughtering and feasting upon large numbers of livestock with the singing of school children and a Christian religious service. He received absolutely no response from the headmen until after Controleur Brouwer intervened by bringing pressure to bear on the key figure in the defiance, Pong Maramba. Maramba was persuaded to contribute a pig to the festivities, which brought a counteroffer from his major rival, $\mathrm{Ne}^{\prime}$ Mattandung of Balusu, to contribute a buffalo. After other chiefs followed suit the success of the festival was assured, with some twenty-four pigs and a buffalo offered for slaughter and the promise that all the headmen would attend as well. The government's timely intervention on behalf of the missionary signalled a new cooperation between government and mission in an effort to break what they jointly perceived as stubborn resistance from the powerful old headmen. 6 s

The full extent of their cooperation became clearer in the following two months. Pong Maramba spent several short periods in the Rantepao jail on various charges before he was finally hauled off to Palopo to stand trial for extortion. 6 While the headman of the most populous district in Rantepao awaited trial, van de Loosdrecht spelled out the motivation behind the charges in a letter to his mentor, Kruyt. He felt depressed about the response in Rantepao to his evangelizing, which was proving less favorable than that from Makale where much less effort had been expended. While local knowledge of Christianity had increased in Rantepao, the political situation had deteriorated:

-.. the political situation is still wretched, which all the old chiefs have a hand in; the worst enemy is Pong Maramba. Mr. Brouwer [the controleur] is beginning to clean up the situation, supported by the new Assistant Resident Nobele.

I think that Pong Maramba, who already sits in Palopo, will be the first to go; Brouwer is presently investigating his vile case. This fellow has stolen almost all the sawahs he has. People assess his worth at a tidy million. He does nothing of benefit with all his wealth, merely extorting from the people. It is too bad that this man is so impervious to the truth. He is our greatest adversary and maintains everyone here against us. But we will go steadily forward and in God's time the harvest will come here as it has in Posso."'?

65. Van de Loosdrecht, $A D V$, October 1916, pp. 96-97.

66. S. Pandin, interview, August 15, 1978, Ujung Pandang; F. K. Sarangallo, interview, February 1, 1978, Ke'te (Toraja); $A D V$, November 1916, p. 104.

67. Letter from A. A, van de Loosdrecht to A. C. Kruyt, February 22, 1916, Rantepao (AHK). 
Maramba's reluctance to convert to Christianity was a great disappointment to van de Loosdrecht, one that he took personally. It was all the more galling since he was aware that Maramba himself had originally requested that missionaries come to Rantepao. 6 . He sensed that the powerful headman was now going out of his way to show more interest in Islam than in Christianity while van de Loosdrecht was seeking to convert him. Maramba's presence loomed over the missionary almost wherever he went in the onderafdeeling. Earlier in 1915 van de Loosdrecht had confronted his own powerlessness in the face of a dysentery epidemic in Bori. His previous admonitions not to provide sacrifices to the deata to ward off disease went unheeded when Maramba, on advice from Islamic teachers, instructed the headman there that each affected household should throw an egg and a needle into the river. On another occasion, when van de Loosdrecht made an unannounced visit to Maramba's house, he walked in on an Islamic teacher talking with the headman." In -subsequent conversations with the missionary, Maramba displayed the kind of knowledge of Christianity (apparently gained through his discussions with Muslims) that thoroughly dismayed van de Loosdrecht. Fluent in Bugis, bef riended by Islamic teachers, having built a burial structure for his mother topped by the unmistakable dome of Islamic architecture, Maramba was showing ominous signs of not only rejecting Christianity but also possibly embracing Islam. If the great headman of Rantepao converted to Islam, his immeasurable influence threatened to sweep his thousands of clients with him.

The government's criminal court in Palopo found Pong Maramba guilty on twenty-four counts of extortion, and sentenced him to fifteen years in exile. Until the ship came to take Maramba to Java, van de Loosdrecht sought to convert him in his prison cell. The headman's refusal did not have the drama or the finality of the oaths taken against Christianity by some of his fellow headmen; he simply maintained, the mission journal records, that he was still unable to convert. ${ }^{70}$

Maramba's exile was merely the opening scene in a coordinated effort to undo the old guard. Similar criminal charges followed against $\mathrm{Ne}^{\prime} \mathrm{Kulu}$ and Danduru of Buntao, and $\mathrm{Ne}^{\prime}$ Mattandung of Balusu was rumored to be next, because of accusations from van de Loosdrecht. The missionary also leveled charges of both incest and extortion against the Nanggala Parenge, while complaints filed by the missionary led to headmen in Sa'dan and Bori being punished for neglect of duty. 11 Van de Loosdrecht insisted he would pursue this offensive, "so long as extortion is not totally rooted out, so long as the belief is not abandoned that our Government will leave Toraja before long, so long as the hope is not given up that the old conditions of plunder and thievery shall once again return, so long ... so long, in sum, until the Lord with his Holy Spirit comes to breathe (life) into these spiritually dead and God's wonder is seen. ..." 72

Van de Loosdrecht's invective brought together the strands of his somewhat muddled conception of what was "wrong" with Torajan society. It was less

68. Letter from A. C. Kruyt to A. A. van de Loosdrecht, April 4, 1916, Pendolo; $A D V$, November 1916, p. 104 .

69. Van de Loosdrecht, ADV, August 1915, p. 63; December 1914, p. 101.

70. $A D V$, November 1916, p. 104.

71. Van de Loosdrecht, ADV, January 1918, p. 4; August 1917, p. 68.

72. Van de Loosdrecht, $A D V$, February 1918, pp. 9-10. 
an attack on wrongdoing as such than on what was holding back conversion. There can be little doubt that from the standpoint of a Western-legal view of justice, the charges leveled at selected members of the old guard were justified; the point is, however, that nearly any of their contemporaries could also have been convicted by the same criteria. By driving a wedge between those with the determination and power to resist the changes being introduced and those persons sympathetic to a new order, the missionary hoped to create a "movement" toward Christianity. If the government's presence were to become fixed as a given in the people's minds rather than another in a series of passing waves of influence to be ridden out, influential persons would be tempted to accommodate it. In this process, if social conditions were to stabilize to the point that the lower classes did not remain so dependent on the powerful to protect them from starvation and raids (or the current variant), they might be drawn to a religion offering them a new status.

\section{Resolution: Torajan}

By 1917 a complex mosaic of grievances toward mission and government existed in the Sa'dan highlands. If the government was seen as the agent for making decisions that affected people's lives in the tondok, the mission was viewed as the intelligence-gathering apparatus funneling reports from teachers, students, and the missionaries themselves to the controleur. While gathering damaging information through his active participation in village affairs, the missionary dispensed unsettling pronouncements on Torajan custom and the god of the Kompania, confirming with words what his actions had already told them: "the Kompania wills that you become Christian." The controleur, by sending troops and armed police to haul off to the Rantepao jail the parents of truant students, put steel into the missionary's request for manpower and materials to build the schools, and enforced his passion against gambling and cockfighting. While van de Loosdrecht might say "that the mission asks and urges but the government orders and punishes," the Torajan was more likely to conclude that "the mission asks and urges, then the government orders and punishes." 73 The distinction was indeed too fine to have meaning in the Torajan context of 1917.

The combined weight of mission and government cooperation put a new strain on the indigenous religion. The missionaries told villagers to test the falsehood of the pemali (taboo) against such things as eating rice during the time between a family member's death and burial, and asserted that the souls of sacrificed animals did not go with the deceased to the af terworld--a belief that underpinned so much of Torajan religion and social behavior. The fears that the Dutch were out to obliterate the indigenous religion reached their height when the governor journeyed to Rantepao on March 2, 1917 to meet with the missionaries in what Torajans widely held to be a plot to convert all Torajans to Christianity. 74

73. Van de Loosdrecht, ADV, August 1917, p. 69.

74. Unless otherwise noted, the discussion of the governor's visit is based on the reports of two government investigations: W. Fryling, confidential report from the investigation into the death of A. A. van de Loosdrecht, Verbaal 27-5- 1918-97, mailrapport 1836/17 (Colonial Archive, The Hague), E. A. J. Nobele, secret government report over the death of A. A. van de Loosdrecht), Palopo, August 20, 1917 (AHK). 
The rumor had some basis in truth. Indeed, the governor was meeting with the controleurs from Makale and Rantepao and the mission personnel (including Prins and van de Loosdrecht) to discuss van de Loosdrecht's proposal to abolish not only cockfighting but the death feast itself and ban markets on Sundays, essentially transforming the market system from a six-day cycle to a seven-day cycle, with the Sabbath off. The meeting ended with the governor supporting a reduction in the number of days allowed for cockfighting during a funeral ceremony and vigorous enforcement of the prohibition against gambling, which had been regularly ignored by headmen. He apparently rejected the idea of banning the Sunday market, but conceded that no corvee be performed by Christians on Sunday. His position on the death feast is not mentioned, but we may assume that he probably agreed with van der Veen that abolition would be premature, though heavy cutting at death feasts should be discouraged.

The incomplete information leaking from this meeting made a prof ound impression on Torajan headmen. Many of them met at the Rantepao headmen's hall and made strong statements of protest against the anticipated forced Christianization. The rumor soon spread that the death feast, cockfighting, and the Sunday market would all be abolished. Indeed, the signs had been around them for some time. It had become so difficult to gain a permit for cockfighting at a funeral ceremony that only one in ten applications was favorably received. If the controleur thought that a cockfight had been held too recently, he would deny permission even to the most prominent of applicants, on the grounds that otherwise people would make the rounds from cockfight to cockfight, squandering their money.

The immediate fears stimulated by the governor's presence in Rantepao exacerbated long-standing animosities generated by the village schools. These schools, in the minds of most villagers, were a kind of corvée. New construction required too much hauling of wood from distant sources, especially in the heavily populated Sa'dan heartland, and too of ten the wood gathered was rejected as unsuitable; this angered both the laborers, who had hauled it, and the headmen, who were punished for not having seen to it that the work was properly completed. People in two districts felt badly aggrieved because they had had to supply deliveries of wood for a total of three schools, four houses for teachers and missionaries, as well as numerous stalls for two new markets. This was in addition to the regular corvé labor they had to provide on local roads and the main road to Palopo. Having little sense of the school's utility to the village, people focused on their own losses, in terms of children's labor in the fields or at home, and the cost of clothing them for school. They resented being jailed or fined when their children were absent from school, and many objected to the taxing of death feasts to support the school through the "fonds sekolah," even though this supposedly voluntary contribution of 10 percent had actually been proposed by Pong Mangassa of Tondon. In sum, while most headmen and their people may not initially have objected to the idea of having a school in their village, once it was built they found it objectionable and gave it little support.

In the final analysis, the perceived attack on indigenous religion and custom, combined with the villagers' objections to the schools, might not have produced the eventual violent reaction they did had not the mission and government made such a determined effort to undercut some of the stalwarts of the old elite. By selectively removing and sending into exile the linchpins of the elite, the Dutch may have failed to recognize the general sense of alarm this caused among the headmen. If it could happen to Pong Maramba, $\mathrm{Ne}^{\prime} \mathrm{Lapu}$, and Danduru, why not to $\mathrm{Ne}^{\prime}$ Mattandung or anyone viewed as opposing 
the mission? As Kruyt concluded, "... it never would have come to a death if something else had not been added, namely van de Loosdrecht's cooperation to bring to light the crooked ways of the chiefs." 25 Combined with his airing of such matters as land seizures and elite participation in slave trading, and his shift in sympathy toward the "dispossessed," the missionary's thrust against the stalwarts raised their fears to the breaking point.

Opposition began to mount against the increased interference of mission and government in village affairs. In keeping with the still fissiparous nature of Torajan political organization, the response was largely spontaneous, and it cannot be said to have characterized the highlands as a whole. To the extent that there was a perceivable pattern, the opposition came mainly from the more populous, politically influential tondok of the Sa'dan valley in onderafdeeling Rantepao. In contrast, far greater tolerance, to some extent even support, for the mission's penetration came from the peripheral tondok that had been forced to accommodate to their more powerful neighbors prior to 1905 , and which continued to play a subordinate role in the onderafdeeling administration constructed by the new overlords. The picture in onderafdeeling Makale shows similarities to that of Rantepao, particularly in the rapport that had begun to develop between the mission and the tondok peripheral to the Tallu Lembangna (the three populous tondok Makale, Sangalla, and Mengkendek). Perhaps because the mission did not become very active in Makale until 1916, opposition did not grow as fast as in Rantepao; it appears to have peaked there about three years later, with the mysterious burning of missionary Prins house. 76

A few specific instances drawn from 1916 and 1917 serve to illustrate the rising resistance in Rantepao. Van de Loosdrecht had long identified Pangala and Balusu as key districts in which to gain support. His initial optimism there totally faded as Tandibua and $\mathrm{Ne}^{\prime}$ Mattandung gave no backing to the schools in their districts. Pangala, it seemed to him, was the bastion of heathenism, meaning that adherence to the indigenous religion had remained firm there, with little evidence of movement among the elite toward either Islam or Christianity. "T The animosities generated on both sides began to take on personal overtones as these two district heads conf ronted the missionary. Tandibua was suddenly relieved of his position as district head on the usual extortion charges, which doomed the Pangala school as long as he resided in the district. Surreptitiously the sacked headman began to assemble supporters and arms in an old fort west of Pangala. Mattandung, pressed by rumors that he would be arrested, also began to rally his supporters, while the missionary dredged up unsavory charges based on the headman's allegedly bloodthirsty past as a warrior. Mattandung adopted a young tomakaka in the traditional "anak angkat" manner, a practice particularly prevalent in periods of unrest. His adopted son, Pong Massangka of Pangli, was widely known as a daring youth, skilled in cockfighting, who swore he would sooner fight the Kompania than go to jail for gambling. 78

75. Letter from A. C. Kruyt to D. Crommelin, September 1918, Pendolo (AHK).

76. J. Belksma, ADV, April 1921, pp. 26-27.

77. Van de Loosdrecht, ADV, January 1918, p. 3.

78. W. Fryling, "Korte verslag over de maand, Juli 1917," Verbaal 8-4-1918-7, mailrapport 2135/17 (Colonial Archive, The Hague). 
In Sa'dan, opposition centered on the missionary's instructions that a better house had to be built for the guru. The present accommodations were wretched from the mission's point of view, but the unpopularity of the guru and general dislike of the school caused the villagers to refuse to supply labor or materials for anything better. Even when several headmen were prosecuted for "neglect of duty" their resistance did not weaken, which was particularly notable since the Sa'dan district head was not known for his ability or influence. 79

In Nanggala the headmen directed a barrage of accusations against the guru, and student attendance at the school slowed to a trickle. Because of their determination, the headmen finally forced the guru out of the village and the school closed down.so In tondok Bori (Tikala district) the opposition took a different course, and was directed at halting construction of the school and the guru's house before either could be completed. Initially the elite engineered a slowdown, which brought angry complaints from the mission. Ultimately their resistance took a more determined form, when the headmen denied food to any of their retainers who worked on the buildings. Starving out the kaunan in this manner brought construction to a standstill, until the controleur sent armed police into Bori to put down what he chose to interpret as a breach of the corvee obligation there. ${ }^{81}$ To break the boycott the government appointed a member of the elite to supervise each day of construction activity, making him responsible for seeing that the kaunan were properly fed. There is no indication whether or not the controleur's threat to jail any headman continuing to resist was tested. 22

Tondon, the first district to deny labor and materials for use in school construction, remained a source of bitter complaints, ostensibly over a misunderstanding between the chief and a guru from the government school in Rantepao. It later became apparent that the conflict ran deeper and van de Loosdrecht, encountering continued subdued hostility among the elite there, remarked that "a spirit of quiet rebellion rules in Tondon," $"$

Behind the scenes of isolated resistance, the headmen had begun to take positions that envisioned the expulsion of the Dutch. From the beginning, some of them had seen the Dutch as passing overlords destined not to control the highlands for long. As early as 1909, some of the headmen hatched a plot first to attack the Dutch in Makale and Rantepao, then to move on to conquer Palopo and Makassar. 34 Now in 1917 a variety of plots and subplots swept through the more rebellious tondok while in most other, less volatile, villages, the headmen usually chose to keep silent about them. A Tikala village headman did report one arms cache in March 1916, shortly after the exiling of Pong

79. Van de Loosdrecht, $A D V$, January 1918, p. 4.

80. Van de Loosdrecht, ADV, August 1917, p. 68.

81. At the time of this incident, and for several years afterwards, there was still no firm decision from the residential authorities as to whether or not school construction could be considered an obligatory duty. Van de Loosdrecht sought a policy statement from the governor in support of such a position, but appears not to have succeeded. Disappointed, he concluded that school construction was dependent on the good will of the local official.

82. J. Belksma, ADV, June 1918, pp. 42-43.

83. Van de Loosdrecht, $A D V$, January 1918, p. 4.

84. W. Fryling, confidential report, p. 16. 
Maramba; it amounted to three Beaumont rifles, nearly a dozen barrels and bolt assemblies, and a ten-kilo keg of powder. ss On July 21, 1917 the Tikala district head, Arung Langi, and the Bori headman, Pong Arung, reported to the Rantepao prosecutor that $\mathrm{Ne}^{\prime}$ Mattandung's adopted son had organized a gambling party in his kampung; they broadly hinted that "the named persons harbored plans to revolt." " There was no love lost between these two informers and $\mathrm{Ne}^{\prime}$ Mattandung, their animosity originating in the days of Tikala raids into Balusu for slaves and ransom. However, Dutch authorities proved unable to find Mattandung's adopted son.

Vague plans for rebellion had been in the wind since 1916, but they assumed a sense of urgency only af ter the incendiary rumors emanating from the governor's visit to Rantepao swept through the onderafdeeling. Accounts of who was involved vary, but by one Torajan version the conspirators included Tandibua of Pangala, $\mathrm{Ne}^{\prime}$ Mattandung of Balusu, and Mattandung's adopted son Pong Massangka."? The official Dutch investigation also implicated Pong Arung of Bori, who had tried to play both sides. The rebels planned simultaneous attacks on all Dutch compounds in Makale and Rantepao towns, and on the houses of the four missionaries, to drive all the Dutch from the highlands. Arms were collected and stored in preparation for the rebellion, though they apparently consisted mainly of traditional spears and long knives. Given the lack of political unity at the time, the plan, and the preparations for implementing it, seem quite impressive. Before the principal plan had a chance to develop fully, however, the subplot initiated by $\mathrm{Ne}^{\prime}$ Mattandung and his followers prematurely came to a climax.

About July 15, 1917 Pong Massangka led a dozen followers into Rantepao on market day to wait in ambush for Controleur Brouwer, who typically took a walk around the market each day in the late afternoon. Hiding knives in their sarung, the band watched the controleur, with his wife and young son, approach to within two hundred meters (by Brouwer's later reckoning) of where they were hiding behind some trees. Suddenly the child stumbled and fell, beginning to wail. Rather than take the protesting child through the crowded market, Brouwer and his wife decided to return home at once, thwarting the plot of the would-be assassins. 8

When Massangka and his supporters returned to Pangli, Ne' Mattandung held a gambling party for them. They then made a second plan for an assassination, this time of van de Loosdrecht at his house in Barana, just north of Rantepao. On

85. W. Fryling, "Kort verslag over de maand Maart 1916," mailrapport 1301/16 (Indonesian National Archive, Bogor Repository).

86. W. Fryling, confidential report, pp. 5-6.

87. S. J. Sarungu, "Sejarah Peperangan Pong Tiku dengan Belanda tahun 1906-1907" (Rantepao, 1971), pp. 48-49.

88. M. R. Brouwer, Letter to A. C. Kruyt, February 18, 1918, Rantepao (AHK). Torajan accounts of this story coincide with the account Brouwer gained from interrogating Pong Massangka about the incident; in current Torajan accounts, such as Tandilintin's popularized history, the young boy's wailing is given as the reason the controleur returned home, while the fact that his wife was pregnant is given as the reason the Torajan plotters did not then fall upon them (it is taboo). I initially suspected the veracity of this account, but Brouwer's letter confirms that his wife was then in about her fifth or sixth month of pregnancy. 
the evening of the $26 \mathrm{th}$ the group, joined by others who had not participated in the earlier attempt, slaughtered a pig and prepared rice for a ceremonial meal before starting off for the missionary's house. A courier had just returned with word from $\mathrm{Ne}^{\prime}$ Mattandung that he agreed with their plan to attack the missionary. According to one account, lances were stuck into the ground as the conspirators swore an oath of war. Suddenly someone appeared with the news that van de Loosdrecht had been seen at a guru's house in Bori, some twenty minutes away. Under cover of darkness, thirteen of the celebrants then hurried off to carry out their plan.

After the band reached the Bori bridge, the designated assassin left them and approached the porch where the missionary was reading to the guru. Leaping on to the porch, the young warrior plunged his lance through van de Loosdrecht's lower chest; as he slumped to the floor, the dying missionary knocked over the lamp, and flames engulfed the porch as the band slipped away.

Passions pent up over the period of several rice harvests poured out that night and the next. With the active or passive support of many villagers Pong Massangka and his followers swept through Tokarau market an hour away, burning the newly constructed market stalls. They then returned to Pangli where they burned three bridges linking the village with the road to Rantepao-a road resented by Massangka because, without consulting him, the government had confiscated a portion of his rice fields for a right-of-way. "s The inhabitants of Pangli were whipped into an anti-Dutch frenzy, and they built barricades around village entrances, preparing to fight the Dutch troops that they knew would soon arrive. Reports to the assistant resident indicate that the Dutch expected a fierce battle in Pangli.

Controleur Brouwer, with his half-brigade of armed police, proceeded from Bori to Balusu, bypassing the stronghold at Pangli. Two brigades of infantry from Palopo and two from Enrekang were already on their way to deal with any heavy resistance. Brouwer went to Balusu, because he suspected that $\mathrm{Ne}^{\prime}$ Mattandung was somehow involved in the murder of the missionary, a suspicion that was confirmed when the old headman not only refused to meet him but also sent "a ridiculous, skinny pig and a pair of old sick chickens" as full measure of his esteem for the ranking Dutch official in Rantapao. 9 At dusk all the surrounding kampung lit fires in support of Mattandung's truculence, and by the next morning five hundred armed supporters hovered in the hills surrounding the unwelcome authorities. Half a day of cat and mouse left one Torajan dead, shot as he advanced on the messenger bearing a summons to $\mathrm{Ne}^{\prime}$ Mattandung. The stalemate ended with the arrival of the assistant resident with his troops from Palopo and another half-brigade of police from Makale. In the face of this triangular advance, Mattandung's warriors dispersed throughout the hilly terrain, fighting ineffectually with lances and long knives against the Dutch firearms. Several more Torajans were killed and captured and the resistance crumbled. The round-up of rebels and active sympathizers continued for two weeks, with hundreds being detained.

Mattandungts capture and the surrender of Pangli without a fight exposed the weakness of the leadership behind the plots to kill Brouwer and van de Loosdrecht. The more comprehensive plans for rebellion, how ever, were implicating Tandibua of Pangala, Pong Arung of Bori, and numerous other headmen. By mid-

89. $\mathrm{Ne}^{\prime}$ Banding, interview, March 11, 1978, Bori (Toraja).

90. J. Belksma, ADV, December 1917, p. 103. 
August, interrogations had produced arrests of the conspirators involved in the more ambitious plot, and ultimately Pong Massangka surrendered, together with his co-conspirators in the missionary's killing. The various plots to expel the Dutch from the highlands had misfired, and fifty-six persons from onderafdeeling Rantepao were exiled. With the departure of Tandibua and his lieutenants, $\mathrm{Ne}^{t}$ Mattandung and his, Pong Massangka and the tragic Pong Arung (who committed suicide in jail), the steel went out of the Torajan resistance to change--particularly the change dictated by the mission and a sympathetic government. Pong Maramba and Danduru had preceded them, Tangki Langi', an influential headman in Pangala convicted in a sawah dispute, followed. The missionary who succeeded van de Loosdrecht recorded the whispers passing through Bori, the tondok which lost the most prominent tomakaka, as news of their deaths in exile trickled into Rantepao: "the Dutch are killing all our great men." 91

\section{Conclusion}

Why this outbreak of rebellion in July 1917? It arose after several years of grievances that grew out of a tightening of colonial administration throughout South Sulawesi. Reports of refusals to pay taxes and evasion of corvee labor assignments had been increasing since about 1915, around the time when the Dutch administrative machinery was coming to be set firmly in place, 92 The demands for construction of new roads, school and administrative buildings, and assessment of the head tax were by then becoming unavoidable, as they were enforced by local armed police reinforced, if necessary, from the afdeeling capital. Headmen were no longer the masters of their own realms; many of the decisions they were compelled to support emanated from the onderafdeeling capital and beyond. What at first may have seemed little more onerous than the exaggerated tributary claims of Luwu looked very different to the headmen as their own powers came to be circumscribed by a new and more penetrating form of external political control. 93

In Makale-Rantepao, the coming of the mission amplified the effects of this penetration. In addition to the taxes and corvee labor with which people throughout South Sulawesi had to contend there was now the difficult-to-ignore presence of village schools. Villagers of ten resented providing labor and materials for purposes that they barely understood; while officially the headman had to give his consent before school construction could begin, this condition was easily overlooked. Even more important, it was by no means certain that the consent of the "village" head, a creation of the Dutch administration, reflected the feelings of those heading indigenous formal or informal power structures. Most headmen who broke with the administration in 1917 had previously singled out some aspect of the school for criticism.

91. J. Belksma, ADV, February 1921, p. 11.

92. Van de Loosdrecht, $A D V$, May 1916, p. 40.

93. Sampebua makes this point about Pong Massangka and other politically ambitious men like him: "They had their path to influence and riches impeded by the Dutch and the application of a different legal standard. Plunder had been an important part of his income, and this was much more difficult to carry out under Dutch law." Interview, March 11, 1978, Bori (Toraja). 
The school was simply the most visible target for protest. It reminded sensitive headmen of the broader encroachments on their lives that had occurred over the decade of Dutch control. Had these feelings been handled with more sensitivity, more guarantees that their world would not be turned upside down, the rebellion in 1917 probably would not have occurred. Instead, the period 1913-1917 was one of increasingly close cooperation between government and mission to bring about fundamental change in the highlands, with less public assurance that tradition (adat) would be protected here than was generally the case in areas of Dutch rule. Van de Loosdrecht found an ally in the controleur of Rantepao, who was one of a small minority of Netherlands East Indies civil servants who shared the missionary's Gereformeerde (Calvinist) Christianity rather than the more relaxed, liberal Reformed Christianity against which the Dutch Calvinists had rebelled in the late nineteenth century." " This alliance moved the controleur much further along toward providing official support to the GZB than would otherwise have been possible, contributing to the strong impression that the government and mission were working together to convert Torajans to Christianity. They were, in fact, doing so, with support from the highest levels in the Netherlands Indies administration, but the process was to be a much more subtle and long-range project than the rebelling Torajan headmen could have realized. What probably precipitated the rebellion in mid-1917 was the governor's visit to Rantepao, which touched off rumors, not totally unfounded, that the Dutch meant to abolish the death feast and gambling, and Christianize all Torajans. A growing sense that $f$ ew options but open resistance remained was undoubtedly strengthened by Pong Maramba's exile and the investigations being conducted against other headmen who had openly opposed van de Loosdrecht.

Indeed, it is striking that the most dramatic resistance to Dutch rule since Pong Tiku's lengthy resistance to the occupation in 1906 's should have been so devoid of ideological content. One could try to attribute this to the nature of the Dutch inquiry into the rebellion, inclined as most such investigations were to classify peasant rebellions into a few easily dismissable categories, such as "Ratu Adil" (millenarian) in Java and "religious fanaticism" in such strongly Islamic areas as lowland South Sulawesi. Yet even indigenous oral sources bear out the Dutch conclusions. It may be that colonial penetration was not sufficiently advanced to have given rise to religious revivalism. Those resisting the advance still stood firmly enough on an indigenous religious foundation that was almost unconsciously a part of their lives. The entire episode rather seems to have been initiated by an elite that felt it was losing control and was being goaded by a missionary attempting to bypass the elite in order to convert the masses, and thereby attacking the very basis of the social hierarchy.

The number involved in the 1917 rebellion was not large, but its leadership was prominent. This promised possible further disruptions unless the tensions that had precipitated the outburst could be reduced. The government was aware of the fragility of a bureaucracy staffed and supported by so few Dutchmen; "peace and security" depended on the support of the traditional elite. Thus the Torajan rebellion could not be lightly dismissed.

94. Van de Loosdrecht, $A D V$, February 1914, p. 14.

95. On this resistance, see Terance W. Bigalke, "A Social History of 'Tana Toraja' 1870-1965" (PhD dissertation, University of Wisconsin, 1981), pp. 98-116. 
The controleur, with full compliance from the mission, issued orders that Torajans could no longer be summoned from their field labor for impromptu meetings with missionaries nor could they be coerced to attend mission functions. Any request for a village school must come directly from the kampung head, supported by a majority of his villagers, and only voluntary labor could be used to construct future schools and teachers' houses, except when there were extreme shortages of manpower.'6 Soldiers and armed police, who were stationed in the towns, could no longer be dispatched to round up truant village children and drag their parents off to jail, nor could the latter be fined for their children's truancy.97 All these restrictions probably helped to relieve some of the major irritants to high status persons, from whose ranks the mission recruited most of its students at this time, and to reduce the disruptive effects of the school on village society.

These changes in government policy clarified the hierarchy of Dutch authority in Makale-Rantepao, differentiating the compulsory power of the administration from the (in theory) merely persuasive authority of the mission. For the village elite, this meant more freedom to reject out-of-hand the advances of the missionaries and teachers. Yet the changes still left the rivals to the ruling elite with an alternative path to power through the mission, and middle and lower status villagers were not foreclosed from rejecting the prevailing social hierarchy and finding a new source of patronage. This had important consequences for subsequent Torajan history.

96. J. Belksma, ADV, July 1919, pp. 51-52.

97. D. J. van Dijk, "Enkele grepen uit den 25-jarigen Zendingsarbeid te Rantepao," in Om te Gedenken (Delft: van Barneveld, 1938), p. 158. This missionary mentions that after 1917 children could be heard to say, "Tae' namadin diparuku" ("he can't force us"), indicating that they realized coercion could no longer be used to make them attend school. 